A. A. Lvov

\title{
ON THE POSSIBILITY OF FREEDOM BESIDE THE SUBJECT: MICHEL FOUCAULT AND THE ATTEMPT OF OVERCOMING OF THE TELEOLOGY OF MODERN HISTORICISM ${ }^{1}$
}

Philosophy of Modernity had considered and laid two fundamental concepts as its basis: subject and method. In the course of history of thought, subject turned into such an epistemological constant, which became able, first, to establish itself, second, to determine truth and to establish its frameworks. This kind of articulation of subject became apt due to the methods Modernity introduced in the scientific paradigm, and Hegel's ambitious project played here the greatest part. Thus, the philosophy of history became teleological - it elucidates the events in linear perspective gradually to the preset purpose. A task of the recent philosophical investigations, however, was to search for an alternative methodology beside the subject which could establish another programme of realising will to knowledge. This paper discusses Michel Foucault's attempt to oppose the "transversal" philosophy of history to the Modern subjective paradigm in terms of the results he had achieved. Our inquiry becomes possible due to the Foucauldian archaeological method. His original epistemology makes the examination of frameworks of truth of subject as a concept possible. Being formerly a constitutional element, the subject then becomes a methodological problem. Such a consideration of a basic concept in Modern philosophy grants the possibility to study the development and elaboration of the methodological determinism, which supports the development of the pre-Cartesian subject. Concerning the results, we could name, firstly, the reconstruction of the historical retrospective of an element of Modern philosophy's apparatus, and, secondly, an attempt to provoke the question on the possibility of freedom beside subject. Refs 15 .

Keywords: teleology, transversal approach, Michel Foucault, historicism, the practices of the self, the aesthetics of existence, archaeological method.

\section{А. А. Львов}

\section{О ВОЗМОЖНОСТИ СВОБОДЫ ВНЕ СУБЪЕКТА: МИШЕЛЬ ФУКО И ПОПЫТКА ПРЕОДОЛЕНИЯ ТЕЛЕОЛОГИИ НОВОЕВРОПЕЙСКОГО ИСТОРИЦИЗМА}

Новоевропейская философия уже в лице Декарта решительно выдвинула на первый план два основополагающих понятия: субъект и метод. В ходе развития истории мысли субъект превратился в эпистемологическую константу, способную, во-первых, обосновывать самое себя, во-вторых, определять истину и устанавливать границы ее влияния. Подобная артикуляция субъекта была легитимирована предложенными новоевропейской парадигмой методами. Наиболее значительную роль, пожалуй, здесь сыграла грандиозная система философской науки Гегеля. Философия истории, таким образом, оказалась телеологической, то есть выстраивающей события в линейной перспективе пошагового движения к заранее определенной цели. Однако одной из задач философских исследований XX в. был поиск возможностей альтернативной внесубъектной методологии, которая обосновывала бы иную программу реализации воли к знанию. В предлагаемой статье мы обсуждаем попытку Мишеля Фуко противопоставить субъектной парадигме эпохи модерна «трансверсальную» философию истории с точки

Lvov Alexander A.- PhD, Assistant, St. Petersburg State University, 7-9, Universitetskaya nab., St. Petersburg, 199034, Russian Federation; a.lvov@spbu.ru

Львов Александр Александрович - кандидат философских наук, ассистент, Санкт-Петербургский государственный университет, Российская Федерация, 199034, Санкт-Петербург, Университетская наб., 7-9; a.lvov@spbu.ru

1 Статья подготовлена при финансовой поддержке РГНФ в рамках проекта № 15-33-01013 «Философская историография во французской философии XX века».

(c) Санкт-Петербургский государственный университет, 2017 
зрения итогов его «постмодернистского» проекта. Наше исследование становится возможным благодаря применению характерного для Фуко метода археологии гуманитарного знания. Его оригинальная методологическая программа, заявленная им в целом ряде исследований, позволяет, на наш взгляд поставить под сомнение и, возможно, заново определить эпистемологические границы самого субъекта познания. Иначе говоря, наследнику картезианского cogito перестает отводиться фундаментальная роль конституирующего элемента философского познания мира, и он вновь оказывается методологической проблемой. Подобного рода проблематизация одного из наиболее значимых понятий новоевропейской философии позволяет проследить становление методологического детерминизма, идущего рука об руку с возникновением докартезианского субъекта как такового. В результате нашего исследования нам удалось показать, что поиски Фуко альтернативной картезианскому проекту эпистемологической программы можно считать методологически успешными, а, следовательно, и его поиски возможности свободы вне субъекта удавшимися. Библиогр. 15 назв.

Ключевые слова: телеология, трансверсальность, М.Фуко, историцизм, практики себя, эстетика существования, археологический метод.

\section{Introduction}

The issue we analyze in the present paper could be reduced to a simple question, which has been constantly put by many investigators and scholars: is freedom possible beside the paradigm of subjectivity? We know the answers to it; at its cutting edge we find the representatives of postmodernism and poststructuralism, foremost those, who created their papers in the post-World War II France. However, we are primarily interested in the answer given by Michel Foucault as far as it was he who introduced one of the most impressing projects of rethinking of the traditional historical system. The latter, perhaps but Giambattista Vico and his late contemporaries of XVIII century (e. g. Herder), has been understood in the sense of teleology; Foucault tried to represent the whole history in the frameworks of the biographies of truth practices.

As it is well known, the Hegelian system observed as the climax of the Modern doctrine of subject, can find unity in any miscellaneous number of various and abandoned moments in the world history on its way of development of truth. Foucault's epistemology (yet too early to say "methodology") appears to be much more flexible as far as it recognizes the fact that each epoch realizes its immanent will to knowledge depending on its discursive formation. However, this approach is less productive and systematic than the one of Hegel. Does it mean that we face the attempt of overcoming of the Modern historicism's teleology, which is at the same time connected with the searching for freedom beside any subjective forms? We could put this question in another, even more radical way: is the Foucauldian epistemological vein postmodern? Thus, we doubt the frontiers of the Modern methodology as such a field of ontological sense, which (possibly) has exhausted its potentialities and found its succession in the other order of discourse.

We will try to sketch the program of teleological understanding of history as it is represented by the pair of Descartes and Hegel, and then we will consider the counterarguments of the French philosopher of the twentieth century. In the Conclusion we will summarize our own ideas as possible answers to the questions have been put above.

The Hegelian history of philosophy is teleology in which the subject is hypostasized by its exclusive, perpetual being-in-it. Due to this hypostatization the very history be- 
comes the system, order, and truth. In history the subject finds not its existence, but its completion, and it can accomplish in its truth and completeness of being only by obtaining unity and fulfillment in this order. But it is necessary to mean that nothing but method here takes place of "the soul of being" [1, p. 530]. In the course of the Modern philosophy it is method (in Hegel's case, dialectics) which can transfer the meaning of any things or events which are in the sphere of its power. Nevertheless, we do not really speak about one of the instruments, as, say, a Petri dish, or telescope. The method becomes such a mandatory institution on the way of realization of anthropocentric freedom, which eagers to submit society as well as nature itself. Initially it appears to be an experience of submission of cognitive and then practical aspects of life in its social and political sense to the human being on the position of the subject. Konstantin A. Sergeev and Yuri V.Perov said about that the following: "There are traditionally inherited images and patterns of thinking that are fastened to each of us and that burden our mind. The latter is allotted with the urge of being free and powerful, but is not really able to fulfill this urge, for it is lacking of the possibility to have its own experience to search anything freely and on its own due to such an experience and upon the basis of it. Due to the refinement of mind in this constantly renewable experience from traditionally inherited prejudices, the reason itself appears constantly tested in the aspect of reality. At the same time, acquiring its necessary actuality in its own experience indisputable by anything both outer and inner, it appears to be a reason which controls everything including its own experience of freedom, in just cognitive effort at least"2 $[2$, p. 30]. To say it another way, to follow the method means to kill vivid reality by driving it into the dead pattern of the system.

If we speak about efficacy of the research program (in the wider sense) of the Modernity, we have to mention the sphere where the method obtains its power. A philosopher and historian of science Bruno Latour describes the phenomenon of experiment, which had been developed by Galileo and Francis Bacon, in terms of a certain "Constitution", a kind of an agreement which defines the human and 'non-human' beings as the actors in the investigatory net. Namely, he speaks: "Just as the constitution of jurists defines the rights and duties of citizens and the State, the working of justice and the transfer of power, so this Constitution - which I shall spell with a capital $C$ to distinguish it from the political ones - defines humans and nonhumans, their properties and their relations, their abilities and their groupings" [3, p.15]. Thus, peculiarities and attitudes of people and technical means, their competent sphere and the ways of amalgamation, consequently, the relations between the cognitive subject and object, that has been studied by the experimental instruments, become the sphere of laboratory. The term of laboratory gets its immediate importance here; in their "Laboratory Life", B. Latour and S. Woolgar argue even more radically: "Scientific activity is not 'about nature', it is a fierce fight to construct

2 Cf.: «Существуют унаследованные в длительной традиции образцы и схемы мышления, навязываемые каждому из нас и обременяющие сознание, которое наделено стремлением быть свободным и могущественным, но не способно действенно осуществлять это стремление, поскольку оно лишено возможности иметь собственный опыт, чтобы с помощью такого опыта и на его основе свободно и самостоятельно исследовать что бы то ни было. Благодаря очищению разума в этом непрерывно возобновляемом опыте от унаследованных в силу традиции предрассудков разум оказывается сам по себе непрерывно испытуемым в аспекте реальной действенности, и в то же время он, обретая в своем собственном опыте непререкаемую ничем внешним для него и внутренним необходимую ему действенность, оказывается контролирующим все и вся разумом, включая и собственный опыт свободы, хотя бы сначала в сугубо познавательном усилии». 
reality. The laboratory is the workplace and the set of productive forces, which makes construction possible" [4, p. 234]. It is obvious that the power of construction of the reality belongs to the investigator. So we see that a monstrous machine of Modern experiment refueled with Baconian postulate of knowledge as power, has been brought into action by the Cartesian engine of subject-and-object paradigm.

In Hegel's doctrine the concept of ego cogito of Descartes finds its logical consistency. In his sketch on the phenomenon of European nihilism, Martin Heidegger studied the stages of emergence and development of what had received the title of subiectum in Modernity. There are plenty of explanations and interpretations of the origin on the term; to cut a long story short, we will follow Heidegger and say that the Modern subject understands itself as absolute and apparent, and proclaims its own principle, freedom and power. He argues that the Modern freedom is thought as a partly revealed room of the whole panorama of the situation, in which the human being will be able to establish consciously as necessary and mandatory. Thus, the very core of the Modern history consists in this realization of the whole diapason of types of the Modern freedom [5, p. 164]. Thus, in the basis of the Modern Time we find neither Divine revelation, nor the Law of God, but selfconfirmed will of the Man, which becomes the principle of anthropocentrism $[5, \mathrm{p} .164]^{3}$. We certainly do not speak about a suddenly confirmed and unprecedented order of the world, but about a well-thought strategy of subdual of compassing reality outside a human being. Descartes's treatise "The Discourse of the Method" is rather illustrious in this sense. On the one hand, the author is eagerly ready to show everyone who would like to advance in sciences and knowledge how to reach the truth by applying the appropriate method on his own example. On the other hand, he expresses his intimate thought that it is possible "to arrive at knowledge highly useful in life; and in room of the speculative philosophy usually taught in the schools, to discover a practical, by means of which, knowing the force and action of fire, water, air the stars, the heavens, and all the other bodies that surround us, as distinctly as we know the various crafts of our artisans, we might also apply them in the same way to all the uses to which they are adapted, and thus render ourselves the lords and possessors of nature" [7, p. 123]. The mentioned terms are "general terms of physics", i. e., corresponding to such a form of knowledge that can only be veracious (as it is well-known, in Modernity comparing to Antiquity and Middle Age, the truth has been understood as veracity, or certitudo) [8, p. 23-24], as far as there is a trustworthy method which could be applied to find and demonstrate the truth.

Foucault's (as, generally speaking, the whole postmodernism's) crusade against Descartes is an attempt to think about the entity beside the method, that is, beside the anthropocentric frameworks; for, as we have already seen, in method one obtains the consistence of the subject. The latter becomes the one who 'follows one's way' (which is the literal meaning of $\mu \dot{\varepsilon} \theta 0 \delta o \varsigma)$. It means, that the language does not stay the home of the being any longer (as it was in Heidegger's thought), but its discursive practice, that embraces the presumption of will to truth, the history. The latter is flexible and vivid only if it is not chained by the method, but is free to develop in its own discursive field, and each time it leaves the evidences and clues of dwelling of the truth on this direct isolated temporal level to the investigators.

${ }^{3}$ Let us note that a thorough study of this issue we find in the idea of Konstantin A. Sergeev, who investigated the Renaissance epoch as the origin of the Modern anthropocentricism, vide: [6]. 
However, what's here the deal? Namely, if we insist on the fact that we release the Man out of rigid frameworks of the system and his subjectivity; if we consciously struggle against Modern anthropocentrism, what becomes lying in the basis of the world, if not the Man himself in the function of subject? - To say it another way, how is the Man's freedom possible beside the methodical thinking of the truth?

\section{II}

This is, as we understand it, the very formulation of the core question of Foucault's philosophical studies. Indeed, in any papers of the French thinker one may find that the lack of methodology is helped out with poetical, even artistic search for the possibilities of freedom. As far as we can judge, the sign of Nietzscheism takes place in this aspect of Foucault's works.

We know that in his early career Michel Foucault had experienced radical influence of Heidegger's thought on him. He confessed that he came to Nietzsche via Heidegger as well [vide: 9, p. 51]. However, the very detour consisted in practical rather than theoretical presumptions of the French philosopher. After 1968 when Foucault faced the embodied idea of power as such, he realized that "the power does not weigh against us, but passes through us and comes out from us: we are the power ourselves"4 [10, p. 402]. Nietzsche discussed that very decisively in his works. The tragedy of a young and daring classicist depicted in his early writings consisted in unsuccessful attempts to find the way out from desolate chambers of scholarship and desperate urge to the fresh air of selfness, out from the prison cell of dusty philology: "In the most obvious way, since the reawakening of Alexandrian-Roman antiquity in the fifteenth century, after a long and difficult to describe interval, we have come closer to this condition" [11, p. 80]. Let us note that he means the condition of revival, rise and fall of the German myth. Nietzsche continues: "Up on the heights this same abundant desire for knowledge, the same insatiable happiness in discovery, the same immense secularization, alongside a homeless wandering around, a greedy thronging at foreign tables, a reckless idolizing of the present, or an apathetic, numbed turning away, with everything sub specie saeculi, of the 'present age'; these same symptoms lead us to suspect the same lack at the heart of this culture, the destruction of myth" [11, p. 80]. This artistic approach to his language and thought Nietzsche will foster further, using it to express his freedom and independence from the academic philosophy.

It is interesting to observe the subject matter of the prophet of Uebermensch as it was put in his early texts through the prism of Hegelianism. One cannot ignore Hegel's influence on Foucault, especially in the aspect of the issue of freedom demonstrated above. Hegel appears to be the "shade alter-ego" of the French fighter with subjectivity, and this "shade" (in the course of papers dedicated to his life and writings one may find the phrase "Hegel's voice" to describe this circumstance of Foucault's intellectual life) was introduced to him by no one else but his teacher and neo-Marxist thinker Louis Althusser.

Althusser was one of the most independent and genuine thinkers in the Marxist field in XX century. In his efforts to reconstruct theory of Marxism free of the Hegelianism, he found that the identity of immediate being and nothing, which was proclaimed by Hegel,

${ }^{4}$ Cf.: «Власть не довлеет над нами, но проходит сквозь нас и от нас же исходит; мы сами власть». 
is "an ideological myth of the philosophy of origin". This myth brings us into the element of thinking, where Hegel's gigantic speculative system develops with all its might. Marx himself stood for the practical rather than theoretical approach; that is why the very dialectics which (we refer to this as a commonplace circumstance in the field of contemporary Humanities) he bore from his idealist predecessor represents not a speculative, but a very practical method [12, p. 16]. The same logic we find in the works of Karl Marx's successors. In his famous lecture on Lenin as a philosopher, Althusser delivers an eloquent and anticipating Foucault's thought characteristic of how to understand the Marxist theory of truth: "Marx founds the science of history where there were previously only philosophies of history. When I say that Marx organized a theoretical system of scientific concepts in the domain previously monopolized by philosophies of history, I am extending a metaphor which is no more than a metaphor: for it suggests that Marx replaced ideological theories with a scientific theory in a uniform space, that of History. In reality, this domain itself was reorganized" (italics added) [13, p. 38].

Michel Foucault thoroughly considered this epistemological sphere and the way it transforms in his inaugural address at College de France that was published under the title "The Order of Discourse". To sum up, we could define the discourse as an order of speech, in which the truth can be articulated. The latter is not a constant throughout the course of world history - as it has already been put above - but it represents a certain "structure" (the term which Foucault himself tends not to mention, but it becomes rather appropriate in this context), in the frameworks of which it realizes in its own genuine sense. By whom does it realize? Hegel's possible answer could be: by the Absolute Subject, or the Weltgeist. The gravity of such an answer would be so powerful that the concept of the Spirit (Geist) would embody anything able to appear as a reasonable subject. Foucault argues that the discourse can also realize the truth of the outcasts that historically found themselves out of the track of history and society, and fell under the repressive functions of civil and state apparatus. Here is his eloquent explication of this paradoxical order of articulation of truth: "Certainly, as a proposition, the division between true and false is neither arbitrary, nor modifiable, nor institutional, nor violent. Putting the question in different terms, however - asking what has been, what still is, throughout our discourse, this will to truth which has survived throughout so many centuries of our history; or if we ask what is, in its very general form, the kind of division governing our will to knowledge - then we may well discern something like a system of exclusion (historical, modifiable, institutionally constraining) in the process of development" [14, p. 218]. However, various types of discourses can represent themselves various types of truth; thus, the truth can be represented in such a discursive sphere in which history appears, and the latter, to Foucault's mind, is free and in these terms opposite to a scientific system.

In fact, the analysis of different discourses in the historical perspective of freedom gave the French philosopher the opportunity to establish his archaeological method. Foucault demonstrates that this method deals with a completely different field of knowledge $[14$, p. 350] rather than the sciences themselves or the analysis of scientific discourses; on the other hand, he warns us about a subtle character of the studied discourses in the very beginning of this methodological course: "Discourse must not be referred to the distant presence of the origin, but treated as and when it occurs. These pre-existing forms of continuity, all these syntheses that are accepted without question, must remain in suspense" [14, p.25]. In other words, we encounter a paradox: firstly, the discontinuity of the dis- 
course on which Foucault insists as an epistemological supposition, does not play a part of an obstacle for its unity. For there are many discursive formations which are based upon the principles of distribution of the epistemological powers within them rather than the structure of the one or any unconditional nexus (one or several links) within the interdiscursive fields: "It would probably be wrong therefore to seek in the existence of these themes the principles of the individualization of a discourse. Should they not be sought rather in the dispersion of the points of choice that the discourse leaves free? In the different possibilities that it opens of reanimating already existing themes, of arousing opposed strategies, of giving way to irreconcilable interests, of making it possible, with a particular set of concepts, to play different games? Rather than seeking the permanence of themes, images, and opinions through time, rather than retracing the dialectic of their conflicts in order to individualize groups of statements, could one not rather mark out the dispersion of the points of choice, and define prior to any option, to any thematic preference, a field of strategic possibilities?" [14, p. 36-37] Secondly, however, the philosopher himself confesses that the discursive practice does not coincides with those types of scientific development that it is able to bring into life, and the knowledge it helps us to obtain is "neither an unfinished prototype nor the by-product to be found in daily life of a constituted science" [14, p. 184]. Thus, science appears to be something less stable in terms of epistemology than the discursive practice; to paraphrase it, if we are equipped with the archaeological stuff that Foucault provides us with in his writings, we can fail to find the pearl of science in a fruitless shell of discursive formation digging into the layers of various discursive formations of different epochs and analyzing the variety and ensembles of interdiscursive formations.

As for us, we think that here Foucault reaches a deadlock: trying to create a transverse (the concept of F. Guattari which was first applied to Foucauldian theory by G. Deleuze, vide $[10$, p. 220, 540-546]) history, i. e., to study the "transverse section" of time of life and activity of the West-European part of humanity, he still works in the frames of conceptual net of Modernity. It is known that the medieval authors were not aware of the classical Latin of Caesar or rhetorical eloquence of Seneca, and they wrote a weird amalgam of vernacular and Latin, created a kind of lingua franca of pre-Erasmus lore. Foucault himself was certainly much more sophisticated than the scholars of the Dark Ages, and he could not ignore the fact that he tries to reach balance between two completely opposite languages: the Modern and the anti-Cartesian ones of freedom of history that we could try to comprehend beside the established subjective practices. Along with this issue one more question arises here: how do we think about truth if it is accessible in the action rather than in the concept? For history itself finds its expression in the concepts, and it cannot rise beside the historical discourse qua history. Even if we try to think about history leaving method as organizing and structuralizing principle apart, it will nevertheless represent a kind of Lebenswelt of the one who finds himself in such a discourse. Here one may observe two possible ways: either to stay on the position of linear teleology and watch the perspective movement of history, or to change everything drastically and, in accordance with Deleuze and Guattari, say that the surrounding reality develops as a mirror in front of us, in which the psychic processes reflect (metaphorically speaking, se in speculo contemplari, as Apuleius puts it). Proceeding the latter way we get the project of "willing machines", but the question of technics (as Fragen nach der Technik) has already been discussed by Heidegger. 
Foucault, however, chooses his own path by rejigging the question. If, as it was from the end of 1970s, he was interested in the principal possibility of history beside subject, in his later years he tended to sketch out the boundaries of the history of subject as such. If it is not possible to create a nonlinear version of history, one will probably succeed in demonstrating how the subject shaped into the habitual Cartesian practice and became the container of truth? Perhaps, it is possible to describe the development of subject and point at its boundaries by that? Concluding his lectures course of 1980-1981 entitled "Subjectivity and Truth", Foucault says that one can see how far we are yet to answer to the question of how and why was sex oppressed in terms of the previous hypotheses. We have to speak about the acts and pleasure rather than the wishes. Consequently, we are discussing the possibilities to create the self via various life techniques, not the oppression by the power of prohibition or law. Developing his investigation, he argues that it is necessary to show how a long tradition of joining the sex and the subject had been established rather than the phenomenon of keeping sex in a distance ${ }^{5}[15$, p. 378]. It is obvious that the very phenomenon of sexuality was taken by Foucault as an illustrious example of ethical and aesthetical syncretism: it becomes impossible to study the subject as developing if not to observe the very boundaries which it set for itself as road signs, along which it consciously proceeds. Such an epistemological but hardly methodological move connected with investigations into the "practices of the self", or as he called them himself, "aesthetics of the self" appeared to be fruitful and afforded him to lay the basis of what we can consider to be a separate discipline - the hermeneutics of the subject. The paramount of Foucault's works became a three-volume research of the sphere of care of self as the power practices that form around the arising subject. The last volume was published in 1984, the year of the philosopher's death.

\section{Conclusion}

Thus, as we have seen, the Hegelian philosophy of history of thought postulates the movement from one moment to another and the very possibility of such transition as the immanent logic of thought, or method. This method is intended to reveal the immanent contradictions in the notions so far as the notion develops: each moment absorbs antithesis in itself finding the potentials to repeal it. As for Foucault, he supposes that there exists a universal "background" in which any possible epistemological game of the words and things (les mots et les choses) takes place rather than a universal method, that is inherent to any period of history of thought. This background of the universal "will to truth" appears dappled with miscellaneous details, which add distinctiveness and authenticity to various and taken separately from each other "layers" of knowledge. Indeed, if we discuss that, for instance, the scientia of the Middle Ages was dismissed by a radically different project of Modern mathesis universalis, - will this mean that we are discussing different forms that the will to knowledge acquires step by step on its path of development rather than differ-

5 Cf.: «Мы видим, насколько все это далеко от такой истории сексуальности, которая была бы организована вокруг старой доброй гипотезы подавления и ее обычных вопросов: как и почему подавлен секс? Речь идет об актах и об удовольствиях, а не о желании. Речь идет об образовании себя через разного рода техники жизни, а не о подавлении при помощи запрета и закона. Речь идет не о том, чтобы показать, каким образом секс удерживался на расстоянии, но - о том, как было положено начало той долгой истории, которая в наших обществах устанавливает связь между сексом и субъектом». 
ent methodologies? The scholars point at this subtle passage on the way from constructing the sense in the past to its description programs in Foucault's writing: "Archaeology is not a universal method that is applicable to the entire spheres of knowledge; rather, we can speak of some approach to the investigation of this or that sphere of knowledge taking into account its origin. The archaeology of knowledge represents itself a kind of a space of thought and practice, within which a human being is absent as a subject. Not only is a "human being" not here, but no research methodology as well"6 [10, p. 451]. Does not the French philosopher provide us with, to put it, a common denominator, a distinctive unity of his own thought that could prove and justify his reject of "meta-narrate" (J.-F. Lyotard's term) as epistemologically feasible?

In contrast to Hegel who regarded the method to be die Seele des seins (the soul of being), Foucault always keeps in mind an important but not quite obvious assumption: each epoch tends to reveal and realize its own peculiar type of knowledge. All these "objective", "historical", "universe", etc. - one can find plenty of epithets to express the contemporary Weltanschauung but not to the very core of the issue - are only the fragments of a huge picture that represents thoroughly depicted and separated from each other layers of various discourses in the frameworks of which the articulation of this kind of will takes place. Foucault starts from the Nietzschean premise to read the whole history of thought as an adventurous enterprise of one's own personal subjectivity, absolutely free from the dogmatism of university.

Thus, we think that the first question we have formulated demands a positive answer. In Foucault's writings of 1976-1984 we find, it is true, an attempt to overcome the teleology of Modern historicism. Searching for freedom beside the forms of subjectivity herewith is being conducted within the very subject. That makes the latter become an interdiscursive field in the frameworks of which various forms of practices of power are realizing as far as the very subject is still being under construction.

Then the second question we have formulated demands a positive answer as well. Foucault must have thought himself to become a precursor of post-modernism: by the latter we do not mean a notorious term that the common sense provides us with (namely, "the philosophy after 1960s"), but substantial overcoming of the Hegelian methodological totality. By opposing radical freedom of truth in different discourses of history to nasty schematization of the Modern method, Foucault (to our mind) made an effort to go beyond the system, within which the organizing principle of sense was nothing but subject. Many aspects of research have been only sketched out by the French thinker, but nonetheless he gave us an insight of what stands beyond the curtain of powerful disciplinary practice of the Modern knowledge at his own peril.

\section{References}

1. Heidegger M. Gegel' i greki [Hegel and the Greeks]. Heidegger M. Vremia i bytie [Being and Time]. St. Petersburg, Nauka, 2007, pp. 527-541. (In Russian)

${ }^{6}$ Cf:: «Археология не является универсальным методом, пригодным для всех областей знания; скорее, речь может идти о некотором подходе к исследованию той или иной области знания с учетом ее происхождения. Археология знания представляет собой своего рода пространство мысли и практики, в котором человек как суверенный субъект отсутствует. Здесь нет не только “человека”, но и никакой методологии исследования». 
2. Sergeev K. A., Perov Iu. V. Gegel' i sovremennoe istoricheskoe soznanie [Hegel, and the Contemporary Historical Consciousness]. Hegel G. W. F. Lektsii po istorii filosofii [Lectures on the History of Philosophy], Book 3. St. Petersburg, Nauka, 2006, pp. 5-82. (In Russian)

3. Latour B. We Have Never Been Modern. Cambridge, Massachusetts, Harvard University Press, 1993. ix +157 p. (Russ. ed.: Latour B. Novogo vremeni ne bylo. St.Petersburg, Publ. Evrop. un-ta v S. Peterburge, 2006. 240 p.)

4. Latour B. Woolgar S.Laboratory Life. The Construction of Scientific Facts. Princeton, New Jersey, 1986. $294 \mathrm{p}$.

5. Heidegger M. Evropeiskii nigilizm [The European Nihilism]. Heidegger M. Vremia i bytie [Being and Time]. St. Petersburg, Nauka, 2007, pp. 87-245. (In Russian)

6. Sergeev K.A. Renessansnye osnovaniia antropotsentrizma [The Renaissance Foundations of Anthropocentrism]. St. Petersgurg, Nauka, 2007. 591 p. (In Russian)

7. Descartes R. Discourse on the Method of Rightly Conducting One's Reason and of Seeking Truth (Guttenberg Project). Available at: http://www.gutenberg.org/files/59/59-h/59-h.htm part4 (accessed: 13.12.2016) (Russ. ed.: Dekart R. Rassuzhdenie o metode. Dekart R. Sochineniia [Works]. St.Petersburg, Nauka, 2006, pp. 93-131.)

8. Sergeev K. A., Perov Iu. V. Gegelevskaia istoriia filosofii v kontekste novoevropeiskoi metafiziki [The Hegelian Philosophy of History in the Context of the Modern Metaphysics]. Hegel G. W. F. Lektsii po istorii filosofii [Lectures on the History of Philosophy], Book 3. St. Petersburg, Nauka, 2006, pp. 5-61. (In Russian)

9. Eribon D. Michel Foucault. Moscow, Molodaia gvardiia Publ., 1996. 378 p. (In Russian)

10. D’iakov A.V. Mishel' Fuko i ego sovremenniki [Michel Foucault and His Contemporaries]. St. Petersburg, Aleteiia Publ. 2010.672 p. (In Russian)

11. Nietzsche F. The Birth of Tragedy Out of the Spirit of Music. Available at: http://www.holybooks.com/ wp-content/uploads/Nietzsche-The-Birth-of-Tragedy.pdf. (accessed 13.12.2016) (Russ. ed.: Nietzsche F. Rozhdenie tragedii iz dukha muzyki. Nietzsche F. Sochineniia [Works], in 2 vols. Moscow, Mysl', 1990, vol. 1, pp. 47-158.)

12. Naumova E.I. Proekt marksistskoi dialektiki L.Al'tiussera [The Project of L. Althusser's Marxist's Dialectics]. Vestnik Volgogradskogo gosudarstvennogo universiteta, 2013, is. 7, no. 1, pp. 14-17. (In Russian)

13. Althusser L. Lenin and Philosophy and Other Essays. New York and London, Monthly Review Press, 1971. (Russ. ed.: Althusser L. Lenin i filosofiia. Moscow, Ad Marginem Publ., 2005. 175 p.)

14. Foucault M. The Archaeology of Knowledge and The Discourse of Language. New York, Pantheon Books, 1972. 245 p. (Russ. ed.: Foucault M. Poriadok diskursa. Foucault M. Volia k istine: Po tu storonu znaniia, vlasti i seksual'nosti. Moscow, Magisterium, Publ. Kastal', 1996, pp. 47-96.)

15. Foucault M. Volia $k$ istine: po tu storonu znaniia, vlasti $i$ seksualnosti [The Will to Truth. Beyond Power, Knowledge and Sexuality]. Moscow, Kastal' Publ., 1996. 447 p. (In Russian)

For citation: Lvov A. A. On the possibility of freedom beside subject: Michel Foucault and the attempt of overcoming of the Modern historicism's teleology. Vestnik SPbSU. Philosophy and Conflict studies, 2017, vol.33, issue 3, pp. 316-325. DOI: 10.21638/11701/spbu17.2017.307.

Received 15.12.2016

Accepted 16.03.2017 